\title{
Blinding, brunescent traumatic cataract: overcoming barriers to care for a refugee from Myanmar
}

\author{
He J Li, ${ }^{1}$ Konstantinos T Tsaousis, ${ }^{1,2}$ Nicholas Reiter, ${ }^{1}$ Alan Crandall ${ }^{1}$
}

${ }^{1} J o h n$ A Moran Eye Center, Salt Lake City, Utah, USA ${ }^{2}$ Department of Ophthalmology, Leicester Royal Infirmary, Leicester, UK

\section{Correspondence to} Konstantinos T Tsaousis, konstantinos.tsaousis@gmail. com

Accepted 28 February 2016

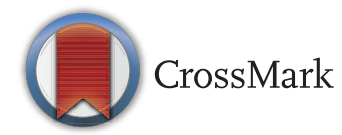

To cite: Li HJ, Tsaousis KT Reiter N, et al. BMJ Case Rep Published online: [please include Day Month Year] doi:10.1136/bcr-2016214831

\section{DESCRIPTION}

Figure 1 is of an extremely hard and black (dark mahogany colour) cataractous lens removed from the left eye of a 51-year-old refugee from Myanmar who recently arrived in the USA. He was struck, 25 years ago in Myanmar, by an aerial bomb. The explosion ruptured his right eye. The cataract in his left eye appeared slowly over 1 year. On examination in our clinic, there were flakes of metallic shrapnel still embedded in the cornea of his left eye. Phacoemulsification was unsuccessful in removing the cataract, and extracapsular cataract extraction with scleral fixation of the intraocular lens was performed (video 1). The patient's preoperative visual acuity was hand motion only. One week after the surgery, he was able to count fingers at two feet. Myanmar has some of the highest rates of blindness in the world; cataract remains the most common cause of blindness. ${ }^{1}$ The mechanisms of injury, laterality and time before treatment are important factors that affect visual outcomes in traumatic cataracts. ${ }^{2}$ The most common barrier to surgical treatment for cataracts in Myanmar include high cost of surgery, fear of surgery and associated complications, and lack of time/family support. ${ }^{3}$ These barriers are compounded when refugees migrate to other countries where the unfamiliar environment and language barrier exacerbate suspicion and fear of medical intervention. Special care should be taken to comprehensively engage and educate the refugee so that surgical logistics, such as transportation and home care, can be well coordinated. Engendering trust among the refugee community can encourage more people to take beneficial medical intervention.

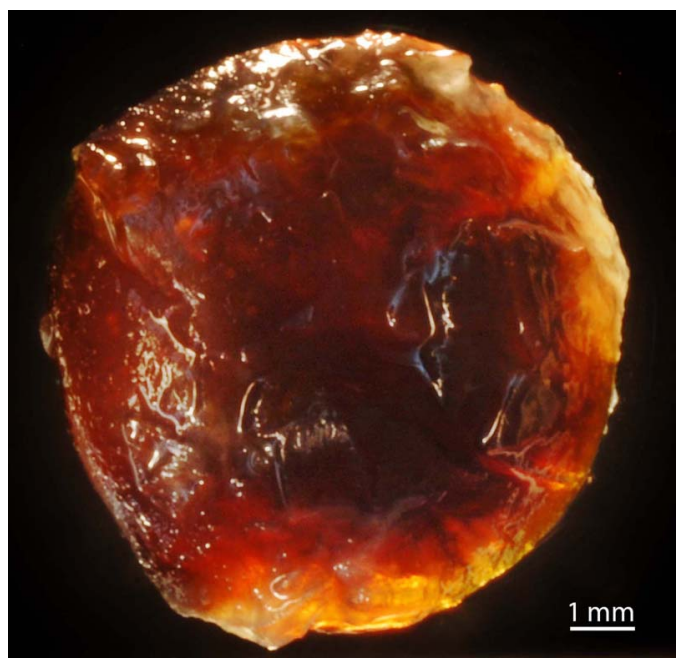

Figure 1 The crystalline lens of the patient. Note the extremely dark colour of the lens.

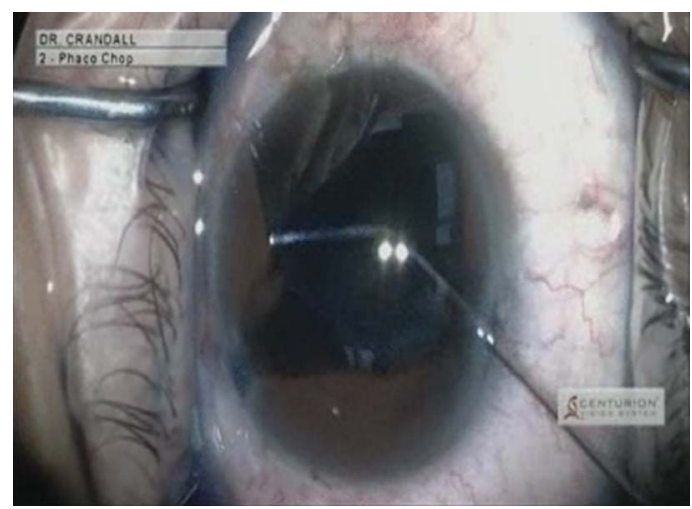

Video 1 Important steps of the cataract operation.

\section{Learning points}

- Traumatic cataracts are challenging cases to treat. Because the mechanism of injury varies between cases and there is a likely hood of associated ocular injuries, the visual outcomes are difficult to predict. Imaging techniques such as ultrasonography and anterior chamber optical coherence tomography scan can help elucidate the patient's associated injuries. Even modest improvements in visual acuity can represent significant improvement to the patient's well-being.

- While cost is a leading barrier to cataract surgery, other reasons include excessive fear and lack of understanding about cataract surgery. Cataract surgery has proven to be safe and effective, and the visual outcomes can change a person's life, especially someone who is young. While patients have the final decision in surgical intervention, surgeons should stress the benefits of cataract surgery and assuage the disproportionate fear of surgical intervention that often exists among the refugee population.

Funding This report has been supported by an unrestricted grant from Research to Prevent Blindness, Inc, New York, to the Department of Ophthalmology and Visual Sciences, University of Utah. KTT received a scholarship (2015) from the Hellenic Society of Intraocular Implants and Refractive Surgery for postgraduate training.

Competing interests None declared.

Patient consent Obtained.

Provenance and peer review Not commissioned; externally peer reviewed. 


\section{REFERENCES}

1 Nemet AY, Nemet P, Cohn G, et al. Causes of blindness in rural Myanmar (Burma): Mount Popa Taung-Kalat Blindness Prevention Project. Clin Ophthalmol 2009:3:413-21.

2 Shah M, Shah S, Upadhyay $P$, et al. Controversies in traumatic cataract classification and management: a review. Can J Ophthalmol 2013;48:251-8.
3 Athanasiov PA, Casson RJ, Newland HS, et al. Cataract surgical coverage and self-reported barriers to cataract surgery in a rural Myanmar population. Clin Experiment Ophthalmol 2008;36:521-5.

Copyright 2016 BMJ Publishing Group. All rights reserved. For permission to reuse any of this content visit http://group.bmj.com/group/rights-licensing/permissions.

BMJ Case Report Fellows may re-use this article for personal use and teaching without any further permission.

Become a Fellow of BMJ Case Reports today and you can:

- Submit as many cases as you like

- Enjoy fast sympathetic peer review and rapid publication of accepted articles

- Access all the published articles

- Re-use any of the published material for personal use and teaching without further permission

For information on Institutional Fellowships contact consortiasales@bmjgroup.com

Visit casereports.bmj.com for more articles like this and to become a Fellow 